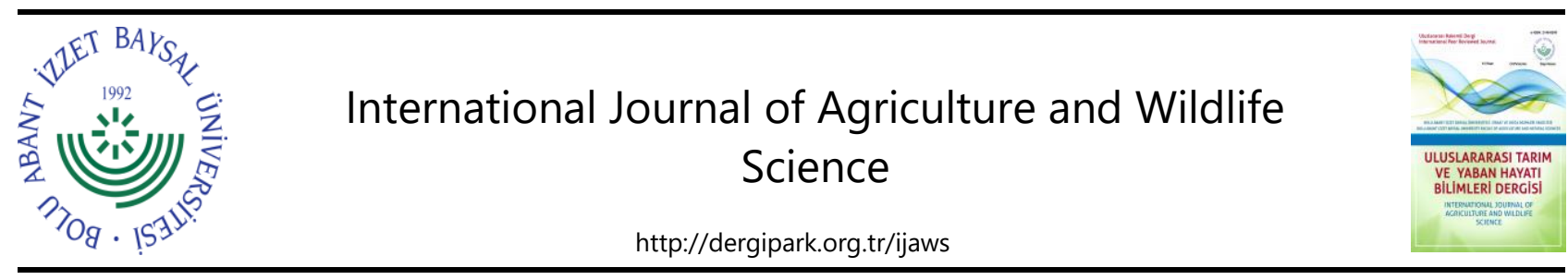

Research Article

\title{
Unusual Winter Activity Observations of Two Newt Species (Ommatotriton ophryticus \& Triturus ivanbureschi) from the Anatolian Peninsula
}

\author{
Muammer Kurnaz ${ }^{1}$ (D) , Mehmet Kürşat Şahin ${ }^{2 *}$ \\ 'Department of Medical Services and Techniques, Kelkit Vocational School of Health Services, Gümüşhane University, \\ Gümüşhane, Turkey \\ 2Department of Biology, Kamil Özdag Faculty of Science, Karamanoğlu Mehmetbey University, Karaman, Turkey
}

Received: 09.02.2021

Accepted: 12.04 .2021

\section{Keywords:}

The northern banded newt, Balkan crested newt, hibernation, Salamandridae, Turkey

\section{Corresponding author} yasambilimci.kursat@gmail.com

Abstract. Interactions between the internal regulation and the environment drive the biophysiological patterns of amphibians. It is well known phenomenon that newts in the northern hemisphere are tend to have hibernation strategies in winter seasons. However, the winter activity record for newts is quite rare. Therefore, we would like to report two winter activity cases from Anatolia, Turkey via two newt species: The northern banded newt (Ommatotriton ophryticus) from Ordu and Balkan crested newt (Triturus ivanbureschi) from Çanakkale. The striking outcomes of this study are that the Northern Banded Newt demonstrates winter activity from another locality apart from Trabzon, and the Balkan Crested Newt has been observed in winter for the first time in its natural habitat. However, it is more important that to document these winter activities are remarkable to provide valuable preliminary data for interpreting the global climate change dynamics in local cases.
\end{abstract}

\section{Anadolu Yarımadası'ndan İki Semender Türünün (Ommatotriton ophryticus \& Triturus ivanbureschi) Olağandışı Kış Aktivitesi Gözlemleri}

\begin{abstract}
Anahtar kelimeler:
Şeritli Karadeniz Semenderi, Pürtüklü Semender, hibernasyon, Salamandridae, Türkiye
\end{abstract}

Özet. İç düzenleme ve çevre arasındaki etkileşimler, amfibilerin biyofizyolojik örüntülerini yönlendirir. Kuzey yarımküredeki semenderlerin kış uykusu stratejisine sahip oldukları iyi bilinen bir olgudur. Bununla birlikte, semenderler için kış dönemi aktivite kaydı oldukça nadirdir. Bu nedenle, bu çalışma ile Ordu'udan Şeritli Karadeniz Semenderi (Ommatotriton ophryticus) ve Çanakkale'den Balkan Pürtüklü Semenderi (Triturus ivanbureschi) ile Anadolu'dan (Türkiye) iki kış aktivitesi kaydı verilmiştir. Bu çalışmanın dikkat çekici çıktıları, Şeritli Karadeniz Semenderi'nin Trabzon dışında başka bir lokaliteden de kış aktivitesi göstermesi ve Pürtüklü Semender'in ise ilk kez doğal ortamlarında kış aktivitesi gözleminin verilmiş olmasıdır. Bununla birlikte, bu tarz kış aktivitelerini belgelemek, lokal vakalar ile küresel iklim değişikliği dinamiklerini yorumlamada değerli ön veriler sağlaması nedeniyle dikkate değerdir. 


\section{INTRODUCTION}

Ectotherm animals, like amphibians in northern climatic zones are forced into overwintering due to seasonal periods of low temperatures (Ultsch, 1989). Since amphibian species are remarkably dependent on moisture and water, their trade-off with the abiotic conditions of their habitats are very crucial for these creatures. Their poikilothermic thermoregulation represents the dependency on the temperature of the environment that they live in, and this is such an undeniable fact under these circumstances. In other words, very cold environments limit their ability to move, and therefore, it becomes difficult for them to forage, escape from their predators and maintain their quality of life. In order to find a solution to these difficulties, they hibernate especially during the winter months and remain asleep until the air temperature rises (Ultsch, 1989). However, amphibians can be active in their microhabitats with suitable temperatures for their lives in winter (Covaciu-Marcov et al., 2011; Sas et al., 2012; Iftime and Iftime 2017). Rana dalmatina (Sas et al., 2012), Salamandra salamandra (Degani and Mendelssohn, 1982), Bufotes variabilis (Altunışık, 2019). Epidalea viridis (Covaciu-Marcov et al., 2011) and Ommatotriton ophryticus (Kuzmin, 2005) have some cases of winter activities in the northern hemisphere's amphibians. One of the best winter activity case from Turkey was reported via northern banded newt $(O$. ophryticus) that has been active almost a whole winter season in a locality from the Northern Anatolia (Bülbül and Koç, 2020).

The northern banded newt (Ommatotriton ophryticus) and Balkan crested newt (Triturus ivanbureschi), that are given as investigated species in this study, are two amphibian species inhabiting in Turkey. While O. ophryticus is distributed in northeastern of Anatolia, the other newt species ( $T$. ivanbureschi) is distributed western and northwestern of this peninsula (Baran et al., 2021). Both newts go into hibernation, and this bioregulation's duration is generally between September / October and March (Amphibia Web 2021). However, a different activity from a population in northeastern Turkey has been reported for northern banded newt (Bülbül and Koç, 2020). In this study, it was reported that it kept performing its vital activities between December and March.

Here, we would like to report new winter activities of these newts. Moreover, the activity case for the Balkan crested newt (T. ivanbureschi) in one of its native distributional range, Anatolia was documented for the first time within present study.

\section{MATERIAL AND METHOD}

In this study, the north-east and north-west specimens of two newt species has been reported in Turkey (Figure 1). While the northern banded newt specimens were found from the Kökenli District (Ordu; GPS data: $40.91 \mathrm{~N}$, $37.83 \mathrm{E}, 200 \mathrm{~m}$ asl), the Balkan rough newt specimen was from from Şahinli-Lapseki (Çanakkale; GPS data: 40.30 $\mathrm{N}, 26.75 \mathrm{E}, 270 \mathrm{~m}$ asl). The sexes of individuals belonging to two species were determined by looking at the presence of crista (Bülbül and Koç, 2020).

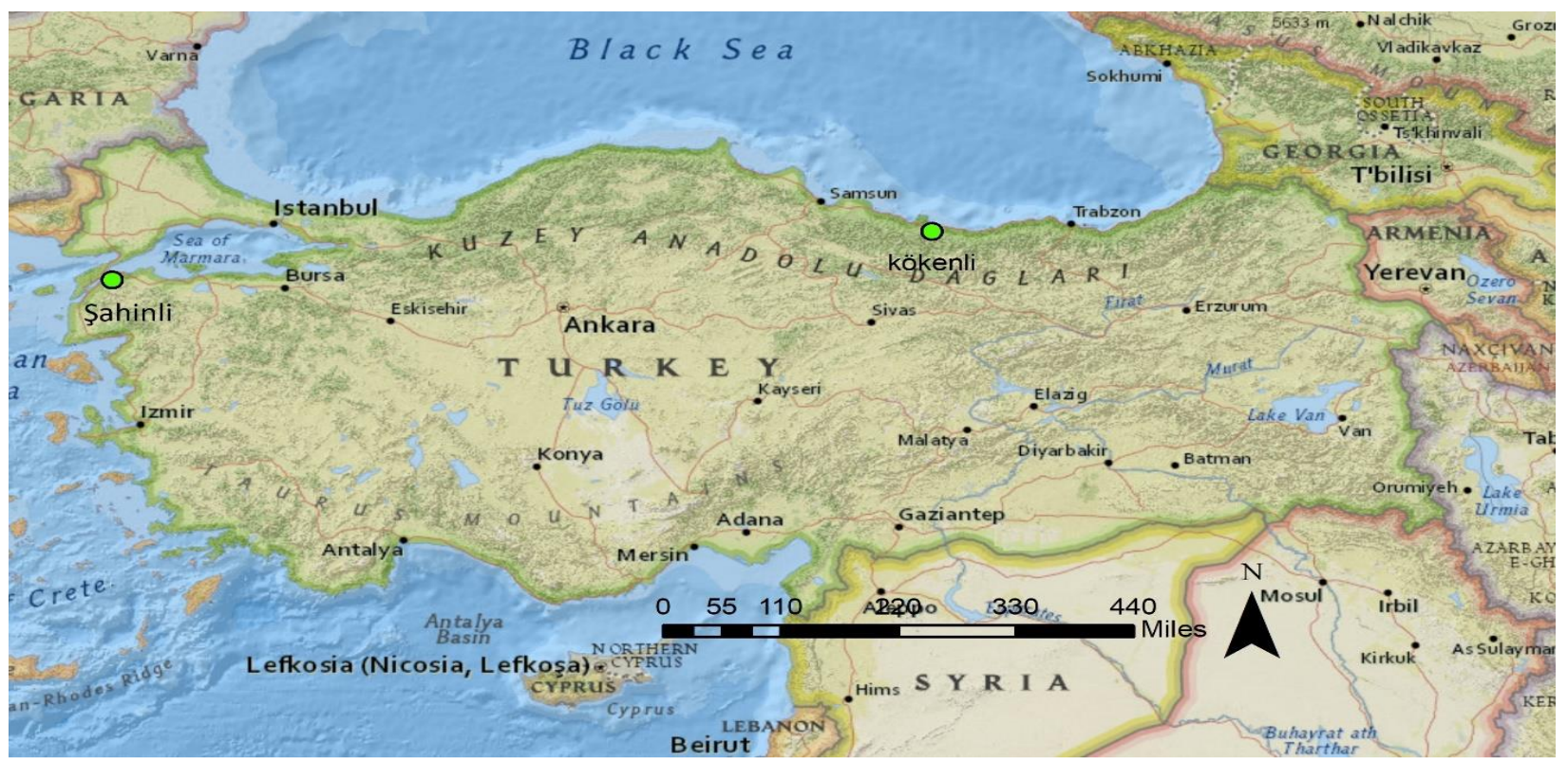

Figure 1. The map shows observed activity localities of two newt species (green circles).

Şekil 1. iki semender türünde aktivite gözlenen noktaları gösteren harita (yeşil noktalar). 
Kurnaz and Şahin, Unusual Winter Activity Observations of Two Newt Species (Ommatotriton ophryticus \& Triturus ivanbureschi) from the Anatolian Peninsula

On the other hand, abiotic factors such as water temperature, air temperature and soil temperature in the areas where the specimens were found were also recorded. After all specimens were photographed and the required data collected, they were released to their natural habitats.

\section{RESULTS}

All newts were observed in January 2021. While the northern banded newt was observed on 8th January, the Balkan crested newt was on the 11th day of this month. 17 individuals (14 males and 3 females) were observed in their original habitat where the northern banded newt is located (Figure 2). However, only one female was observed from the Balkan crested newt in its habitat (Figure 3). The air temperature, moisture of the weather, substrate temperature ( $1 \mathrm{~cm}$ above the ground) and the pond temperatures of both localities were given in Table 1. However, the pond temperature was not measured for the Balkan crested newt, because the observed newt specimen was not found in an area near a pond.

Table 1. Some climatic values of studied localities.

Çizelge 1. Çalışılan alanlara ait bazı iklimsel değerler.

\begin{tabular}{lll}
\hline & Kökenli District, Ordu & Şahinli District, Çanakkale \\
\cline { 2 - 3 } Air temperature & $13^{\circ} \mathrm{C}$ & $21^{\circ} \mathrm{C}$ \\
Moisture & $54 \%$ & $72 \%$ \\
Substrate temperature & $16^{\circ} \mathrm{C}$ & $19^{\circ} \mathrm{C}$ \\
Pond temperature & $17^{\circ} \mathrm{C}$ & $\mathrm{N} / \mathrm{A}$ \\
\hline
\end{tabular}

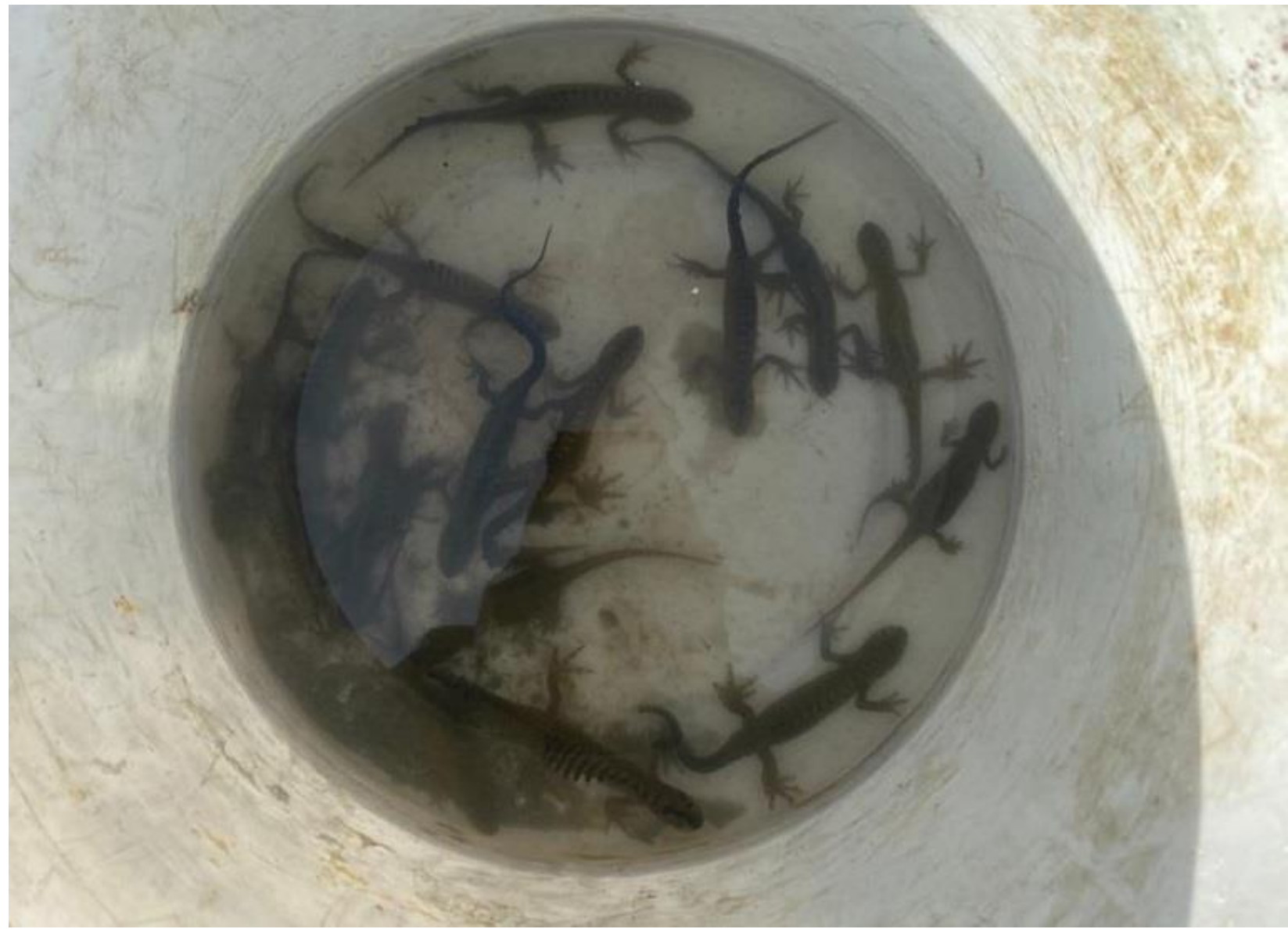

Figure 2. The northern banded newts (O. ophryticus) observed in Kökenli-Ordu on January 8, 2021.

Şekil 2. 8 Ocak 2021 tarihinde Kökenli - Ordu'da gözlenen Şeritli Karadeniz Semenderleri (O. ophryticus). 


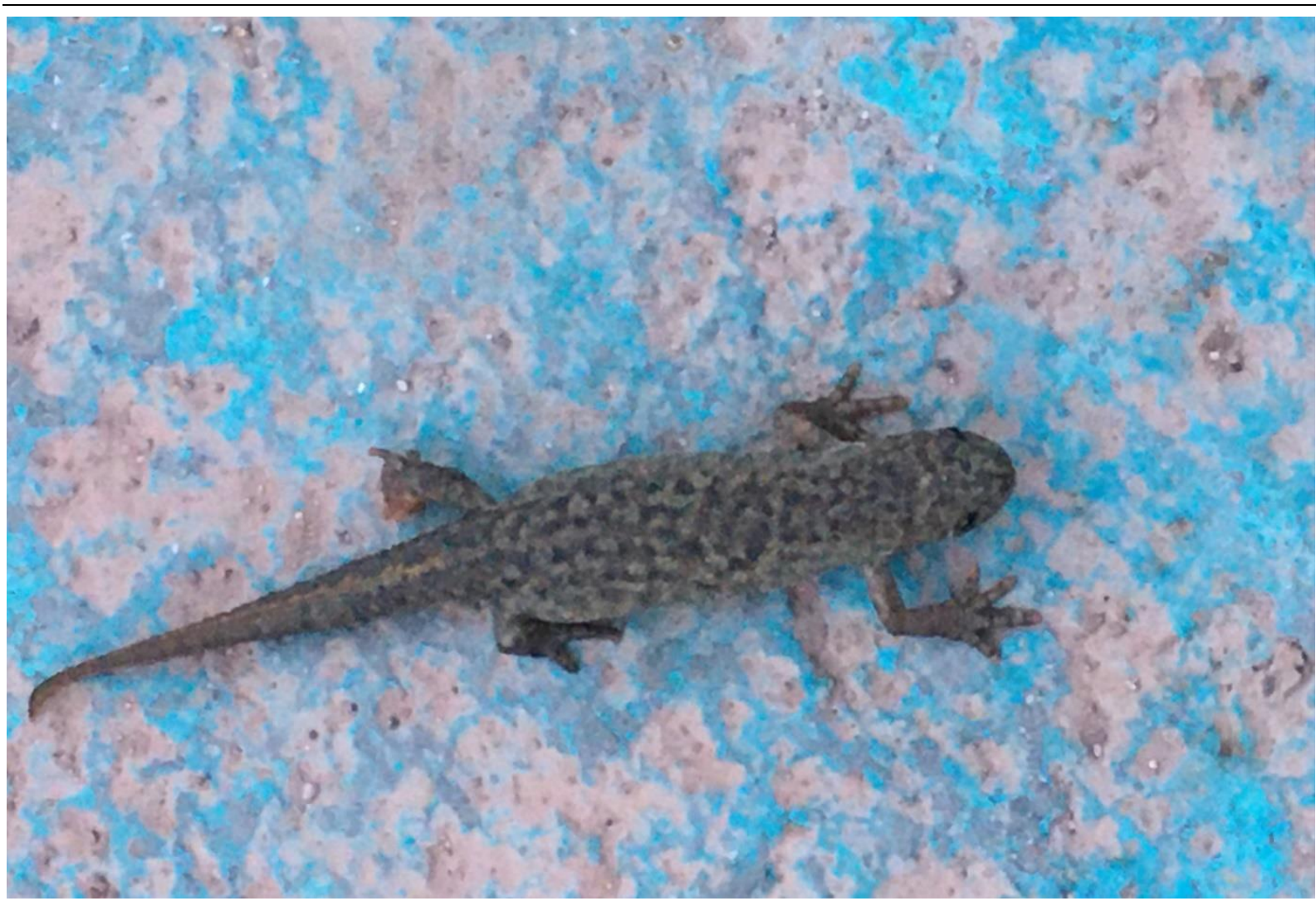

Figure 3. The Balkan crested newt (T. ivanbureschi) observed in Şahinli, Lapseki-Çanakkale on January 11, 2021. Şekil 3. 11 Ocak 2021 tarihinde Şahinli, Lapseki - Çanakkale'de gözlenen Pürtüklü Semender (T. ivanbureschi).

\section{DISCUSSION}

Due to amphibians are poikilothermic animals, their body temperatures are directly related to the environment (Moss 2010). Especially for newts which prefer aquatic life, the temperature of the water they live in, is very important for their activities. In other words, the temperature of the environment in which they live directly affects their bioregulation activities, i.e. reproduction, selection of mate, foraging, escaping from predators, in short, all of their vital activities (Bülbül and Koç, 2020). In addition to that, the humidity conditions of these environments are also very crucial for the survival of newt species (Green 2017). Due to the newts' outer skins are very sensitive and permeable, they are directly affected by humidity and temperature dynamics (Hillyard, 1999; Vitt and Caldwell, 2013). In addition, the temperature affects many physiological processes such as the rate of oxygen uptake, heart rate, nutrition, digestion, homeostasis (Hillman et al., 2008). It is possible to specify different processes for these two newt species as a report in this study. Because the habitat of the northern banded newt (O. ophryticus) seems to have positively affected almost all of its physiological requirements (Bülbül and Koç, 2020). In other words, it is more like a situation than it looks like an incidental occurrence. The northern banded newt specimens were observed not as individually but as a remarkable population (17 individuals), as if they were spending a day in the spring. On the other hand, the Balkan crested newt ( $T$. ivanbureschi) was observed as a single specimen on the road. Although this situation seems a bit coincidental for this newt, it cannot be ignored that its activity on the road in the following day after its information was given to us, brings the case to the point that the air temperature and humidity were suitable for the species to be active at the mid-winter season.

Hibernation is a physiological mechanism taken in some living organisms due to seasonal changes or disruption of many ecological activities in the environment (Üveges et al., 2016). These creatures tend to protect themselves within the period of time till the diminishing vital needs are found in their microhabitats again via this mechanism. For instance, they slow down the circulation and minimize all physiological activities by reducing the heart rhythm. However, the phenomenon of the substrate temperature is very effective in hibernation. When the temperature in the microhabitat increases and reaches its thermal optima, these organisms are tending to wake up from their sleep/hibernation regardless of other ecological needs (nutrients, predators, etc.) and back to their vital activities to normal. Unfortunately, this situation can sometimes result with bad consequences for these organisms. For example, a newt species that is active with the increase of temperatures in winter will need much nourishment in order to keep on its vital activities. However, due to it cannot forage enough in its microhabitat, 
it will not be able to perform many other vital activities and as a consequence, it will face the danger of mortality. The findings obtained in this study show exactly this risk for the northern banded newt. Ambient temperature and humidity are, of course, sufficient for this animal to wake up from sleep. However, since there are not enough other food sources for insects and newts in January, the prolongation of this activity process and the constant increase of air temperatures in winter will probably affect this species negatively.

On the other hand, the winter activity reports of the northern banded newts in the literature, provided that they may be active throughout the year in some locations (Bülbül and Koç, 2020; Amphibia Web 2021). This situation was also based on the fact that there was no snowfall throughout the year and the temperatures were above the seasonal norms in northern Anatolia, where snowfall and low temperature are expected (Bülbül and Koç, 2020). Regardless, with the recent literature findings, it can be also claimed that global climate change has a great impact on herptile organisms (Henle et al., 2008; Green 2017). Therefore, it affects their vital processes and even unintentionally reduces their chances of survival. It is one of the possible phenomenon that threatens all vitality dynamics. As a conclusion, these reports provide not only beneficial data to document the unusual activities of these organisms, but also a base line for further extensive researches.

\section{CONFLICT OF INTEREST}

The authors declare that there are no conflicts of interest regarding the publication of this article.

\section{DECLARATION OF AUTHOR CONTRIBUTION}

All field studies within the scope of the study and the writing part of the manuscript were carried out by the authors together.

\section{ACKNOWLEDGMENTS}

We are are grateful to Mr. Ruşen KINCAL and Mr. Ekrem AZAK for their preliminary information of these activities of both newts in winter season. Lastly, we would like to thank to two anonymous reviewers for their suggestions on developing the manuscript.

\section{REFERENCES}

Altunışık, A. (2019). A case study on earlier activation of the variable toad, Bufotes variabilis (Pallas, 1769). Biological Diversity and Conservation, 12(2), 38-40.

AmphibiaWeb. (2021). Ommatotriton ophryticus: Northern Banded Newt, http://amphibiaweb.org/species/6655, Access Date: Feb 3, 2021

Baran, İ., Avcı, A., Kumlutaş, Y., Olgun, K., \& Ilgaz, Ç. (2021). Türkiye Amfibi ve Sürüngenleri. Ankara: Palme Publishing. 230 pp [in Turkish].

Bülbül, U., Koç-Gür, H. (2020). The unusual winter activity and negative effects of pollution on breeding of Ommatotriton ophryticus (Berthold, 1846) in Turkey. Sinop University Journal of Natural Science, 5(1), 77-83.

Covaciu-Marcov, S. D., Roşioru, C. L., Sas, I. (2011). Hot winters: new thermal habitats with frogs active in winter in northwestern Romania. North-Western Journal of Zoology, 7(1), 81-86.

Degani, G., Mendelssohn, H. (1982). Seasonal activity of Salamandra salamandra (L.) (Amphibia: Urodela: Salamandridae) in the headwaters of the Jordan River. Israel Journal of Zoology, 31, 77-85.

Green, D. M. (2017). Amphibian breeding phenology trends under climate change: predicting the past to forecast the future. Global Change Biology, 23(2), 646-656.

Henle, K., Dick, D., Harpke, A., Kühn, I., Schweiger, O. \& Settele, J. (2008) Climate change impacts on European Amphibians and Reptiles. Convention on the conservation of European wildlife and natural habitats. 28th meeting 24-27 November, Strasbourg, France. 51 pp.

Hillman, S. S., Withers, P. C., Drewes, R. C., \& Hillyard, S. D. (2008). Ecological and environmental physiology of amphibians. Oxford University Press, USA.

Hillyard, S.D. (1999). Behavioral, molecular and integrative mechanisms of amphibian osmoregulation. Journal of Experimental Zoology, 283(7), 662-674. 
Kurnaz and Şahin, Unusual Winter Activity Observations of Two Newt Species (Ommatotriton ophryticus \& Triturus ivanbureschi) from the Anatolian Peninsula

Iftime, A., Iftime, O. (2017). Data on the populations of Bombina variegata (Amphibian: Anura: Bombinatoridae) from Cozia National Park and its surrounding areas (Vâlcea County, Romania). Travaux du Museum National d'Histoire Naturelle "Grigore Antipa". 54(2), 513-521.

Kuzmin, S. L. (2005). AmphibiaWeb, Ommatotriton ophryticus: Northern Banded Newt, http://amphibiaweb.org/species/6655. Access Date: Feb 3, 2021.

Moss, B. (2010). Ecology of fresh waters: a view for the twenty-first century. John Wiley \& Sons. USA.

Sas, I., Roşioru, C. L., \& Covaciu-Marcov, S. D. (2012). Note on eight new thermal habitats with winter-active amphibians in Western Romania. North-Western Journal of Zoology, 8(2), 382-385.

Ultsch, G. R. (1989). Ecology and physiology of hibernation and overwintering among freshwater fishes, turtles and snakes. Biological Reviews, 64, 435-516.

Üveges, B., Mahr, K., Szederkényi, M., Bókony, V., Hoi, H., \& Hettyey, A. (2016). Experimental evidence for beneficial effects of projected climate change on hibernating amphibians. Scientific Reports, 6(1), 1-7.

Vitt, L. J., \& Caldwell, J. P. (2013). Herpetology: An Introductory Biology of Amphibians and Reptiles. Academic press. USA. 